\title{
21
}

\section{THIRD PARTIES AND THINK TANKS}

\author{
Ebony Bennett
}

Though few seats changed hands, the 2019 federal election produced an unexpected result, shocking the Coalition and Labor and the numerous third-party organisations, think tanks, non-governmental organisations (NGOs), charities and activist groups that engaged in the electoral debate.

Third-party organisations and think tanks play important roles in federal elections. While there are numerous organisations that engage with federal election campaigns, this chapter will discuss the scope and effectiveness of the electoral campaigning activities of progressive organisation GetUp! and its conservative counterpart, Advance Australia, in their target electorates_-including phone banking, doorknocking, paid advertising and generating free media and fundraising. It will also examine the activities of three think tanks in shaping the public policy debate: the Canberra-based think tank The Australia Institute, and the Melbourne-based Grattan Institute and Institute of Public Affairs (IPA).

\section{GetUp! and Captain GetUp}

On election night, Antony Green (2019) tweeted: 'Politics is often about expectations. Tonight's seat numbers are almost exactly the same as in 2016. Then it was worse than expected, this time it is better. And doesn't that change the speeches.' 
Similarly, in 2016, GetUp! was widely credited as a formidable campaigning outfit with the power to topple sitting Liberal MPs from office, raising expectations for its 2019 electoral performance that failed to materialise. Though GetUp! was certainly not the only organisation campaigning in seats such as Bass and Dickson in 2016, it was GetUp! that was largely credited with (or blamed for) Andrew Nikolic losing the seat of Bass and the 5.2 per cent swing against Peter Dutton in the Queensland seat of Dickson, and it was therefore seen as a force in the swing against the incumbent Coalition Government.

GetUp! is now well established as a large and influential organisation in Australian politics, sitting alongside Australia's major established political parties in terms of its membership, organising capacity and ability to mobilise people to action. GetUp! (2019a) describes itself as an independent movement with more than a million members, 'working to build a progressive Australia and bring participation back into our democracy'. GetUp! is unique in Australian politics and it is very effective at irritating the conservative side of politics. It advocates for progressive issues its members care about such as climate change, saving the Australian Broadcasting Corporation (ABC), housing affordability and health care. Its campaigning efforts this election did not meet expectations.

In 2019, GetUp! kept the same election strategy as in 2016, targeting conservative politicians it dubbed 'hard-right blockers' to disrupt their influence in politics. Though the GetUp! campaign was a presence in 29 seats, most of its campaigning focused on MPs labelled by GetUp! members as 'hard-right Liberal-National Party blockers' in the seats of Warringah, Flinders, Boothby, Pearce, Menzies, Dickson and Kooyong, who had wrecked progressive policies and stifled public debate on climate change, refugees, multiculturalism, economics and democratic participation.

GetUp! shortlisted its targeted seats by surveying its members, inviting them in January to nominate the 'hard-right MPs they want booted from Parliament', and subsequently announced Dutton and Tony Abbott as the 'country's most loathed politicians' (GetUp! 2019b). In March 2019, GetUp! (2019c) announced Greg Hunt as its next electoral target (though Hunt is not commonly understood to belong to the Coalition's hard right), citing his role as 'the numbers man for Peter Dutton's failed leadership coup' and his 'terrible record on climate change'. GetUp! then 
expanded its targeted seats from five to seven and aimed to double its volunteers from the 2016 election (3,736). National director Paul Oosting acknowledged it was the organisation's most ambitious approach to date and that GetUp! had set itself a huge task. He was correct.

While GetUp! employed standard election tactics in terms of organising and advertising, with a reported election advertising spend of $\$ 4$ million, its strategy of targeting hard-right blockers was different to most thirdparty campaigns, which focus primarily on marginal seats or on specific issue-based campaigns. Seats such as Kooyong and Menzies were considered safe, even blue-ribbon, Liberal seats, but were part of a tranche of Victorian Liberal seats that were possibly 'up for grabs' following Labor's strong victory at the recent State election. That calculation proved to be overly ambitious, but GetUp! was not alone in making it.

Table 21.1 GetUp!'s 2019 campaign, nationally and for Warringah

\begin{tabular}{|l|r|c|}
\hline & $\begin{array}{r}\text { 2019 National } \\
\text { (Warringah) }\end{array}$ & $\mathbf{2 0 1 6}$ \\
\hline Volunteers & 9,433 & 3,736 \\
& $(1,865)$ & \\
\hline Doorknocks & 36,315 & \\
& $(26,630)$ & \\
\hline Phone calls & 712,039 & 40,218 \\
& $(157,592)$ & \\
\hline Total voter contacts & 748,354 & \\
& $(183,222)$ & \\
\hline
\end{tabular}

Source: Supplied by GetUp! to the author.

Table 21.22019 election outcomes in seats targeted by GetUp!

\begin{tabular}{|l|l|}
\hline Target electorate & Outcome \\
\hline Dickson (QId) & $2.9 \%$ swing to LNP; LNP re-elected with $54.6 \%$ of TPP \\
\hline Warringah (NSW) & $18.3 \%$ swing against LNP; IND defeats LIB with $57.2 \%$ of TPP \\
\hline Flinders (Vic.) & $1.4 \%$ swing to ALP; LIB re-elected with $55.6 \%$ of TPP \\
\hline Menzies (Vic.) & $0.3 \%$ swing to ALP; LIB re-elected with $57.5 \%$ of TPP \\
\hline Kooyong (Vic.) & $7.1 \%$ swing against LNP; LIB re-elected with $55.7 \%$ of TPP \\
\hline Pearce (WA) & $3.9 \%$ swing to LNP; LIB re-elected with $57.5 \%$ of TPP \\
\hline Boothby (SA) & $1.3 \%$ swing to ALP; LIB re-elected with $51.4 \%$ of TPP \\
\hline
\end{tabular}

Source: AEC (2019). 
While Tony Abbott lost his blue-ribbon seat of Warringah to Independent Zali Steggall, no other hard-right blocker targeted by GetUp! lost their seat, leaving former Nationals leader and Member for New England, Barnaby Joyce (in Sky News Australia 2019), to boast on election night: 'Went for the sucker trap again didn't you? Put all your resources into a seat you weren't going to win, so you burned up all your resources in other seats you could have.'

Oosting acknowledged GetUp! had not achieved what it set out to do, but said its strategy was formed and expectations set in the context of a predicted nationwide swing against the government that also failed to materialise. Oosting later denied claims from targeted Liberal candidates Nicolle Flint and Kevin Andrews that they were harassed and slandered by GetUp! (Ferguson 2019).

GetUp! had radically ramped up its phone-banking capacity compared with the 2016 federal election, while its doorknocking efforts appear to have been concentrated in Warringah. However, evidence suggests the ability of tactics such as doorknocking, phone-banking and advertising mail-outs to persuade voters to switch their vote during general elections is limited (Kalla and Broockman 2018).

The tactics employed in the campaign led to questions about whether targeting blockers gave incumbents an 'underdog' status and accusations that the campaign had alienated voters. Benedict Coyne, the Greens candidate for Dickson, told The Guardian:

At the risk of generalising, there is a sense that Dutton was able to play the victim card, you know, 'GetUp! and all these outsiders are coming here to do this to me', and that certainly speaks to his base to come and defend him whether it's true or not. (McGowan 2019)

Dutton's margin in Dickson shrank from 6.7 to 1.6 per cent in 2016; in 2019, there was a 2.9 per cent swing towards him. GetUp! has credited its volunteers with limiting the swing in Dickson to 2.9 per cent (compared with the 4.3 per cent swing to the Coalition across Queensland in 2019).

Third-party campaigns can have persuasive effects when particular candidates take unusually unpopular positions or positions in conflict with the values of their electorates and where third-party campaigns make a special effort to identify persuadable voters (Hersh and Schaffner 2013). Abbott, although a long-term incumbent member, had positions on climate policy that were out of step with those of his electorate. While 
Dutton was the architect of controversial policies as home affairs minister, perhaps his positions were not so far out of step with his electorate of Dickson as those of Abbott with his electorate of Warringah. A clear difference between the successful Warringah campaign and the other seats targeted by GetUp! was the presence of a high-profile and well-respected Independent candidate in Zali Steggall, in addition to a high-profile blocker in Abbott, who was out of touch with his electorate.

Tactics that worked well for GetUp! in 2016 backfired in 2019, although arguably their most prominent mistake occurred in the electorate in which they had their only success. A satirical television ad depicting Abbott as an apathetic surf lifesaver letting someone drown was universally judged a mistake and was withdrawn by GetUp!. A conversation guide for volunteers phone-banking in Treasurer and Deputy Liberal Leader Josh Frydenberg's seat of Kooyong incorrectly instructed them to say that 'Josh Frydenberg was part of the coup that removed Malcolm Turnbull as Prime Minister'. Oosting then made several other errors, including incorrectly describing the Treasurer as the deputy prime minister and then the finance minister, when defending the guide and GetUp! in a live interview on Jon Faine's $A B C$ Mornings program (Faine 2019). The interview was described by some in the media as a 'car crash' (Koziol 2019).

The electoral outcomes in GetUp!'s target seats show the limits of its approach; enthusiastic volunteers and money alone are not enough to shift safe seats. International experience suggests GetUp! could have a more meaningful, persuasive impact if it focused its efforts on issue-based campaigns. Third-party campaigns have had success using doorknocking to increase turnout, but Australia's compulsory voting makes this intervention unnecessary (John and Brannan 2008).

GetUp!'s perceived electoral success in 2016 also provoked a substantial backlash. A complaint from Liberal MP Ben Morton sparked an AEC investigation into whether or not GetUp! should be considered an associated entity of a political party. The complaint-one of a number made after the 2016 federal election-was perceived primarily as an attempt to depict GetUp! as a creature of the Labor Party and the Greens, undermining its reputation for independence. The AEC ultimately concluded for the third time that GetUp! was not an associated entity and ruled that the fact an organisation advocates an agenda on one side of the political spectrum does not mean it is 'operating' for the benefit of all registered parties on that side of the spectrum (AAP 2019). 
Following several failed attempts to start a 'conservative GetUp!' as a counterweight, Advance Australia was launched in November 2018 to little public fanfare, but with the backing of high-profile businessmen, including storage company director Sam Kennard and former $A B C$ chairman Maurice Newman. Its national director is Gerard Benedet, former chief of staff to former Queensland LNP treasurer Tim Nicholls. It had extraordinary early success; while it reported 27,500 members and raised $\$ 395,000$ in donations in March (Koslowski 2019), by the next month, it reported 32,000 members and \$1.7 million in donations for the election (Van Extel 2019) —about half of GetUp!'s election advertising spend.

Advance Australia targeted many of the same electorates as GetUp!, though there is less information available on its target seats, campaign activities or the engagement of its 32,000 members in efforts such as doorknocking and phone-banking.

Advance Australia's campaigning was prominent in Warringah, but it also campaigned against Greens candidate Julian Burnside in Kooyong, Centre Alliance's Rebekha Sharkie in Mayo and Independents Helen Haines in Indi and Julia Banks in Flinders (see Chapter 18, this volume). Looking at Advance Australia's campaign targets, one could argue it was about as successful as its progressive counterpart, GetUp! - which is to say, not very. Neither Burnside nor Banks was elected, but Abbott's loss in Warringah was the most prominent scalp of the campaign. Sharkie was comfortably re-elected in Mayo, while Haines was elected as successor to popular Independent Cathy McGowan in Indi. It is not clear how Advance Australia spent the $\$ 2$ million it raised, whether the money was raised primarily from large donors or whether it followed GetUp!'s example of raising millions of dollars from thousands of small donors. If Advance Australia has a broad base of small donors from which its donations came, it would be the most successful attempt to date to create a 'conservative GetUp!'.

Perhaps the most interesting character to come out of the 2019 election was that of 'Captain GetUp'. Benedet said the role of the mascot was to give people 'the facts about the left-wing activists who support "fake" independents' (SBS 2019). 
The caped crusader was Advance Australia's most visible contribution to the campaign, but his role in exposing the 'political correctness' of his rival was limited. The caped crusader was widely ridiculed upon his debut and was arguably more effective at promoting GetUp! than undermining it. Captain GetUp also caused problems for the Abbott campaign in Warringah when the person inside the costume was filmed inappropriately gyrating against a poster of Steggall (SBS 2019).

Captain GetUp is still active on Twitter, but only time will tell whether Advance Australia is able to provide the conservative side of politics with the membership, volunteers, fundraising and organising capacity, and issue-based campaigning to rival that which GetUp! provides for progressive politics. GetUp! will certainly be examining how best to deploy its considerable resources and the enthusiasm of its members for greater impact in the future.

\section{Think tanks}

Think tanks such as The Australia Institute, the Grattan Institute and the IPA play an influential role in elections by generating ideas that shape the public policy debate and help to popularise certain ideas and policy proposals, and by releasing research reports, engaging with the media, briefing policymakers and engaging with the public via conferences and other events (Stone 1996).

Rather than attempt to define exactly what constitutes a think tank, Stone identifies shared characteristics that distinguish them from other groups: organisational independence, self-determination of research agendas, a strong policy focus, a degree of expertise and a concentration on influencing public debate (James 1998).

The Australia Institute describes itself as 'one of the country's most influential public policy think tanks, conducting research that contributes to a more just, sustainable and peaceful society'; the Grattan Institute describes itself as 'a non-partisan think tank providing independent, rigorous and practical solutions to some of the country's most pressing problems'; while the IPA describes itself as an 'independent, non-profit public policy think tank, dedicated to preserving and strengthening the foundations of economic and political freedom'. Each think tank describes itself as independent, though the media often describes 
The Australia Institute as 'progressive', the IPA as 'conservative' and the Grattan Institute as 'centrist'. None of them is affiliated with a political party, unlike the Menzies Research Centre (Liberal Party), the Chifley Research Centre (ALP), the Page Research Centre (the Nationals) or the Green Institute (Australian Greens), each of which is funded in part by a Commonwealth grant-in-aid. These affiliated groups are not examined in this chapter. Other, unaffiliated think tanks such as the Melbournebased Per Capita were also modelling the impact on families of the competing tax policies on offer in the election but cannot be examined in the confines of this chapter.

While many other organisations seek to influence the public policy debate-including charities and NGOs, trade unions and environmental groups-Abelson (2002: 57-63) asserts that think tanks possess unique attributes that afford them greater opportunity to influence public policy, including their expertise and close ties to policymakers, and calls for a 'holistic' approach to assessing their effectiveness that acknowledges that think tanks 'possess different resources, which, not surprisingly, affect the nature and extent of activities they undertake' and that each will differ in which stage of the policy cycle it prioritises on any given issue: issue articulation, policy formulation and/or policy implementation.

As this book examines the federal election, this chapter will necessarily focus on the effectiveness of the think tanks in issue articulation or 'agenda-setting' and policy formation, not policy implementation. According to Kingdon, 'think tanks may often be unable to influence the final choice made by policymakers, but they can do much to set-and perhaps expand - the limits of respectable debate' (Steelman 2003: 164).

During the 2019 election, The Australia Institute's most effective, but perhaps least visible, contribution to the public policy debate was to shift the economic debate to focus more on revenue. Over the past decade, The Australia Institute has published dozens of research reports on the importance of Australia having a strong revenue base, closing tax loopholes such as negative gearing and the capital gains tax discount, addressing the rising cost to the Budget of superannuation tax concessions and the cost of dividend imputation and franking credit refunds. The overarching purpose of this body of work is to shift the public debate beyond simplistic arguments about debt and deficit towards a more inclusive discussion about the kind of Australia we want to see and how it will be funded. 
The Australia Institute was successful in seeing some of its ideas taken up as policy by Labor and other parties and candidates in both the 2016 and the 2019 elections, including achieving cross-party support to establish an independent anticorruption commission, as well as Labor's policy to abolish franking credit refunds for people who pay no tax. This was effectively labelled by the Coalition as 'Labor's tax on retirees' and made a centrepiece of the scare campaign against Labor.

In terms of agenda-setting, arguably the institute was most effective on the issue of a federal independent commission against corruption. Over several years, The Australia Institute released a series of research reports that established the need for a federal anticorruption commission to fill the gaps in Australia's integrity system. It also commissioned polling that showed such a body would attract support from a majority of voters across the political spectrum (Aulby 2017). The Australia Institute established a National Integrity Committee, comprising former judges such as the Hon. Anthony Whealy QC and renowned corruption fighters such as David Ipp QC to design a blueprint for implementation (National Integrity Committee 2017). In January 2018, in a speech to the National Press Club, Opposition leader Bill Shorten announced that Labor would establish such a commission if it were elected and, by December that year, the government announced it would establish a Commonwealth integrity commission, taking the issue from one rejected by both major parties to a bipartisan issue within just a few years. While Labor's policy stayed close to the blueprint set out by the National Integrity Committee at The Australia Institute, the Coalition's model was weaker in several respects (National Integrity Committee 2019).

On the issue of dividend imputation and franking credits-which became central to the 2019 federal election campaign — a majority of Australians have little understanding or are unaware of what franking credits are or how they work (Essential Research 2018a, 2018b).

The Australia Institute's research set out the case for abolishing the cashing out of franking credits for those who pay no tax and during the campaign it attempted to explain Australia's system of dividend imputation and franking credits and to bust economic myths as they appeared in the media and on social media. As a research body with no advertising budget or organising capacity, the institute's efforts were no match for the scare campaign in terms of reach or effectiveness. 
The Australia Institute's chief economist, Richard Denniss, compared the success of the 'retiree tax' scare campaign with Labor's efforts to promote its policy to eliminate out-of-pocket costs for cancer care:

As one of the architects of the idea that ended up becoming Labor's biggest revenue measure-the $\$ 11$ billion plan (over four years) to abolish tax refunds to people who pay no tax-I can honestly say that I never expected it to wind up at the centre of a national election campaign. Not because I think it's a bad idea—and not because I think political parties should hide their plans the way Abbott hid his plans to slash spending back in 2013 - but because I can say with confidence that almost no one knows what an imputation credit is, and everyone knows what cancer is. (Denniss 2019: 27)

The Australia Institute's most visible contribution to the public policy debate in terms of media coverage was its distributional analysis of the Morrison Government's planned income tax cuts package, which conservatively estimated that at least $\$ 77$ billion of the benefits of tax cuts would go to people earning more than $\$ 180,000$ per year (Grudnoff 2019).

The $\$ 77$ billion figure was first put to Minister for Finance Mathias Cormann by David Speers on Sky News in the first week of the campaign (Sky News Australia 2019). Cormann rejected the figure but provided no official figures. Several different journalists put the figure repeatedly to different ministers during the course of the election campaign, but no government figures were forthcoming. Labor leapt on the refusal of ministers to answer the question and used the $\$ 77$ billion as part of its opposition to the tax cuts package throughout the campaign.

Senator Cormann promised in the first week of the campaign that the government would provide its own distributional analysis, but none was forthcoming. These kinds of distributional analyses of income tax cuts are relatively straightforward and form a standard part of the way the federal Budget measures are critiqued each year; it was the dismissive attitude of the government, as well as its refusal to provide its own Treasury numbers, that was unexpected during this campaign.

The Australia Institute also sponsored an open letter in Melbourne's Age newspaper on 16 May, signed by 62 climate scientists and other prominent Australians, urging the 46th Parliament to make climate change a top priority (The Australia Institute 2019). Prominent signatories included Nobel Prize winners Professor Peter Doherty and Dr Sue Wareham, 
former Australian of the Year Professor Fiona Stanley, former Australian chief scientist Professor Penny Sackett and many of Australia's leading scientists from disciplines including climate change, health, economics, energy and finance. Other research areas covered by The Australia Institute in the lead-up to and during the election campaign period included water buybacks in the Murray-Darling Basin Plan and the impacts of climate change.

The IPA's main election contribution was the manifesto 20 Policies to Fix Australia that it sent to MPs (Roskam and Wild 2019). The manifesto suggested withdrawal from the Paris Agreement, implementation of a flat income tax, legalising nuclear power, abolishing the Renewable Energy Target, ending all subsidies to wind, solar and hydroelectricity generators and privatising the ABC. Many of these were long-term policy objectives the IPA has promoted over several terms of parliament. The IPA characterises the Coalition's repeal of the carbon price in 2014 as one its greatest achievements and a 'victory for mainstream Australians over the political class' (Barro 2019a).

While relatively few of the IPA's issues gained traction during the 2019 federal election campaign-perhaps in part because the Coalition's campaign focused so narrowly on tax cuts-it played an influential role within the Liberal Party in the lead-up to the election and is likely to gain prominence post election during the 46th Parliament.

In previous years, several of the IPA's election demands found favour within the Coalition but met with strong opposition from the public when it came to the policy implementation stage. For example, former prime minister Tony Abbott backed several IPA proposals when he was in Opposition, including its call to scrap Section 18C of the Racial Discrimination Act (Crowe 2019)—an issue that remains in the IPA's 2019 manifesto. However, moves to repeal Section 18C were ultimately abandoned by the Abbott Government following a huge community backlash (Griffiths 2014).

In the lead-up to the 2019 federal election, the IPA proved effective at persuading the Liberal Party to adopt its policy of privatising the ABC. This policy found favour with the Young Liberals, which then put forward a motion to the Liberal Party's federal council calling for the Turnbull Government to privatise the $\mathrm{ABC}$ except for regional services (Norman 2018). The vote was backed by a large majority, including at least four of the party's top federal officials and at least one federal Liberal MP, 
according to footage obtained by the Sydney Morning Herald (Crowe 2019). Communications minister Mitch Fifield was the only Liberal who spoke against the motion, despite having made six complaints about the $\mathrm{ABC}$ in as many months in his role as minister.

This demonstrates the IPA's effectiveness at both agenda-settingsuccessfully catapulting the issue of privatising the $\mathrm{ABC}$ on to the national election campaign agenda - and influencing the policy formulation of the Liberal Party. Ultimately, this policy found little favour in the electorate, as happened with the policy to abolish the cashing out of franking credits. Importantly, despite finding enthusiastic supporters among party members, several ministers went into 'damage control' when news of the vote broke and was met with a strong community backlash. Fearing it would give Labor ammunition to run another 'Mediscare'-style campaign, Treasurer Josh Frydenberg assured voters that the $\mathrm{ABC}$ 'is not going to be sold and it can never be sold' (Remeikis 2019).

In September 2018, the Coalition Government announced it would not be replacing the Renewable Energy Target, which expires in 2020, effectively fulfilling one the IPA's key policies (Sydney Morning Herald 2018). Following the federal election, the IPA's call to legalise nuclear power in Australia has been taken up by the Morrison Government. Energy minister Angus Taylor requested a parliamentary inquiry into the use of nuclear energy in Australia, though he said Australia's moratorium on nuclear energy would remain in place (Macmillan 2019). There is no doubt other parts of the IPA's manifesto, such as removing red tape, have also re-entered the national debate post election.

The Grattan Institute released a research report in March 2019 advocating for the introduction of a universal Medicare-style dental health scheme. The report showed that about 2 million Australians who required dental care in the past year either didn't get it or delayed getting it because of the cost - and the poor and disadvantaged are most likely to miss out on care' (Duckett et al. 2019: 3).

Little more than a month later, and just a few weeks out from the federal election, Labor announced it would introduce dental subsidies for nearly 3 million pensioners (Barro 2019b). The Grattan Institute's CEO, John Daley, said its scheme was 'clearly the basis for the recent ALP election promise to go down this path', but added that 'policy reform always has many parents'. 
The Grattan Institute also joined The Australia Institute in publishing research during the campaign on the income tax cuts package. The Grattan Institute's research estimated, based on the government's own Budget forecasts, that spending cuts of $\$ 40$ billion by 2030 would be required to meet the government's promises. The research received widespread coverage but was dismissed by the Prime Minister as 'absolute complete rubbish' (Hutchens 2019). This is despite the institute working closely with the government to implement education funding reforms just a few years previously, showing that influence over policy implementation on one issue does not necessarily translate to effective advocacy or influence on other policy fronts.

\section{Conclusion}

The 2019 federal election result upended widespread expectations as well as conventional wisdom. Some have argued that the result was a rejection of Labor's progressive policy platform and that low and middle incomeearners abandoned Labor, but as explored in Chapter 12 of this volume, there is little evidence to support these narratives, with economic cleavages remaining largely intact.

While third-party organisations such as GetUp! and Advance Australia are unlikely to change their political bent in response to election results, their tactics, target seats and the resources they devote to election campaigning are more likely to change.

It is difficult to measure the effectiveness of think tanks, as they tend to measure success 'by how much influence they have in shaping public opinion and the policy preferences and choices of leaders' (Abelson 2002: 88-89), which is hard to capture via simple metrics such as media mentions. It is even more difficult to unpick the particular influence of think tanks given other groups such as unions and NGOs seek to have similar influence-sometimes on the same issues. Overall, it is also worth considering how the political climate 'can enhance or diminish the profile of some think tanks' (Abelson 2002: 125-26), waxing and waning with the perceived or actual political fortunes of the political parties in the parliament. 
However, there is no doubt think tanks did help shape and influence the political debate during the 2019 federal election, whether by helping certain issues gain national prominence (agenda-setting) or by persuading political parties to adopt their policies (policy formulation).

The Coalition's unexpected election win left the Morrison Government with a relatively light policy agenda for the new parliament (Murphy 2019), which think tanks will now seek to fill, shape and direct with their own policy agendas.

\section{References}

Abelson, Donald E. 2002. Do Think Tanks Matter? Assessing the Impact of Public Policy Institutes. Montreal: McGill-Queen's University Press. doi.org/10.7202/ 1063734ar.

Aulby, Hannah. 2017. The Case for a Federal Corruption Watchdog. Canberra: The Australia Institute.

Australian Associated Press (AAP). 2019. 'Activists GetUp! ruled independent of parties by Electoral Commission'. SBS News, 18 February. www.sbs.com.au/ news/activists-getup-ruled-independent-of-parties-by-electoral-commission.

Australian Electoral Commission (AEC). 2019. 2019 Federal Election Tally Room. Canberra: AEC. results.aec.gov.au/24310/Website/HouseDefault-24310.htm.

Barro, Christiane. 2019a. 'The think tanks shaping Australia: The Institute of Public Affairs'. The New Daily, 10 June. thenewdaily.com.au/news/national/ 2019/06/10/institute-of-public-affairs/.

Barro, Christiane. 2019b. 'The think tanks shaping Australia: The Grattan Institute'. The New Daily, 12 June. thenewdaily.com.au/news/national/2019/ 06/12/grattan-institute-think-tank/.

Butler, Josh. 2019. 'Inside GetUp!'s ambitious campaign to crush Dutton and the Liberal right'. 10 Daily, 6 May. 10daily.com.au/news/politics/a190506xdrlg/ inside-GetUp!s-ambitious-campaign-to-crush-dutton-and-the-liberalright-20190506.

Cockburn, Paige and Sarah Whyte. 2019. 'GetUp! pulls Tony Abbott lifesaver election ad after widespread criticism'. ABC News, 24 April. abc.net.au/news/ 2019-04-24/GetUp!-pulls-tony-abbott-ad-over-climate-change/11041878. 
Crowe, David. 2018. 'Footage from Liberal Party meeting reveals who voted to sell the ABC'. Sydney Morning Herald, 18 June. smh.com.au/politics/ federal/footage-from-liberal-party-meeting-reveals-who-voted-to-sell-theabc-20180618-p4zm5e.html.

Crowe, David. 2019. 'Coalition MPs urged to sell the ABC and support a flat tax in IPA call'. Sydney Morning Herald, 16 April. www.smh.com.au/federalelection-2019/coalition-mps-urged-to-sell-the-abc-and-support-a-flat-taxin-ipa-call/-20190416-p51 enu.html.

Denniss, Richard. 2019. 'The Morrison Election: What We Know Now'. The Monthly, June: 20-31. themonthly.com.au/issue/2019/june/15593 97600/richard-denniss/morrison-election-what-we-know-now.

Duckett, Stephen, Matt Cowgill and Hal Swerissen. 2019. Filling the Gap: A Universal Dental Care Scheme for Australia. Melbourne: Grattan Institute. grattan.edu.au/report/filling-the-gap/.

Essential Research. 2018a. 'Understanding of franking credits'. Essential Report, 27 March. www.essentialvision.com.au/understanding-franking-credits.

Essential Research. 2018b. 'Dividend imputation'. Essential Report, 4 December. www.essentialvision.com.au/dividend-imputation.

Faine, Jon. 2019. 'Mornings'. ABC Radio Melbourne, 17 April.

Ferguson, Richard. 2019. 'GetUp! chiefs face complaint to parliamentary committee'. The Australian, 18 July.

GetUp!. 2016. Election 2016: People Powered Impact. Sydney: GetUp Limited. cdn.getup.org.au/2037-Getup-Election-Report-MP-2016_(1).pdf.

GetUp!. 2019a. Hitting the hard-right with people power!. Media release, 7 January. Sydney: GetUp Limited. www.getup.org.au/media/releases/2019/01/hittingthe-hard-right-with-people-power/.

GetUp!. 2019b. Dutton, Abbott country's most loathed politicians. Media release, 17 January. Sydney: GetUp Limited. www.getup.org.au/media/releases/2019/ 01/dutton-abbott-country-s-most-loathed/.

GetUp!. 2019c. Greg Hunt the next GetUp target. Media release, 14 March. Sydney: GetUp Limited. www.getup.org.au/media/releases/2019/03/greghunt-the-next-getup-target/.

GetUp!. 2019d. Who? What? How? Sydney: GetUp Limited. www.getup.org.au/ about. 
Green, Antony. 2019. 'Politics is often about expectations'. Twitter, 18 May. twitter.com/antonygreenabc/status/1129751172116566016.

Gregory, Katherine. 2019. 'Federal election 2019: Tony Abbott says Warringah campaign "pretty personal" in secret recording'. ABC News, 12 May. www.abc. net.au/news/2019-05-12/tony-abbott-zali-steggall-getup-advance-australia-inwarringah/11100424.

Griffiths, Emma. 2014. 'Government backtracks on Racial Discrimination Act 18C changes; pushes ahead with tough security laws'. ABC News, 6 August. www.abc.net.au/news/2014-08-05/government-backtracks-on-racialdiscrimination-act-changes $/ 5650030$.

Grudnoff, Matt. 2019. A Bit Rich: A Government Plan to Make Tax Less Progressive. Canberra: The Australia Institute.

Hersh, Eitan and Brian Schaffner. 2013. 'Targeted Campaign Appeals and the Value of Ambiguity'. The Journal of Politics 75(2): 520-34. doi.org/10.1017/ s0022381613000182.

Hutchens, Gareth. 2019. 'Morrison Government tax cuts to come at a cost, analysis shows'. West Australian, [Perth], 16 April. www.thewest.com.au/ politics/federal-election-2019/morrison-government-tax-cuts-to-come-at-acost-analysis-shows-ng-b881171007z.

James, Simon. 1998. 'Diane Stone, Capturing the Political Imagination: Think Tanks and the Political Process'. Public Administration 76(2): 408-10. doi.org/10.1111/1467-9299.00108.

John, Peter and Tessa Brannan. 2008. 'How Different Are Telephoning and Canvassing? Results from a "Get out the Vote" Field Experiment in the British 2005 General Election'. British Journal of Political Science 38(3): 565-74. doi.org/10.1017/s0007123408000288.

Kalla, Joshua and David Broockman. 2018. 'The Minimal Persuasive Effects of Campaign Contact in General Elections: Evidence from 49 Field Experiments'. American Political Science Review 112(1): 148-66. doi.org/ $10.1017 / \mathrm{s} 0003055417000363$.

Koslowski, Max. 2019. 'Meet Gerard Benedet, the man who could save conservatives_or take them down with him'. Sydney Morning Herald, 16 March. www.smh.com.au/politics/federal/meet-gerard-benedet-the-manwho-could-save-conservatives-or-take-them-down-with-him-20190315p51411.html. 
Koziol, Michael. 2019. 'GetUp! boss in car-crash interview over claims Josh Frydenberg was "part of Liberal coup". Sydney Morning Herald, 17 April. www. smh.com.au/federal-election-2019/GetUp!-boss-in-car-crash-interview-overclaims-josh-frydenberg-was-part-of-liberal-coup-20190417-p51f1h.html.

Livingstone, Angus. 2019. “'Dopey” GetUp wasted resources: Barnaby Joyce'. Newcastle Herald, 18 May. www.theherald.com.au/story/6131747/dopeyGetUp-wasted-resources-barnaby-joyce/.

McGowan, Michael. 2019. "'Hindsight is a wonderful thing": How GetUp's election campaign fell flat'. The Guardian, 26 May. www.theguardian.com/ australia-news/2019/may/26/hindsight-is-a-wonderful-thing-how-getupselection-campaign-fell-flat.

Macmillan, Jade. 2019. 'Nuclear power in Australia to be examined by multiparty parliamentary inquiry'. $A B C$ News, 3 August. www.abc.net.au/news/ 2019-08-03/parliamentary-enquiry-to-examine-nuclear-power-in-australia/ 11380666.

Murphy, Katharine. 2019. 'GetUp boss under fire for claim Josh Frydenberg was part of Liberal leadership coup'. The Guardian, 17 April. www.theguardian.com/ australia-news/2019/apr/17/getup-boss-under-fire-for-claim-josh-frydenbergwas-part-of-liberal-leadership-coup.

National Integrity Committee. 2017. The Principles for Designing a National Integrity Commission. Canberra: The Australia Institute.

National Integrity Committee. 2019. Feedback on the Consultation Paper: A Commonwealth Integrity Commission-Proposed Reform. Canberra: The Australia Institute. www.tai.org.au/content/feedback-consultation-papercommonwealth-integrity-commission-proposed-reform.

Norman, Jane. 2018. 'Liberal Party members vote to privatise ABC and move Australia's Israel embassy to Jerusalem'. $A B C$ News, 16 June. www.abc.net.au/ news/2018-06-16/liberal-members-vote-to-privatise-abc-move-embassy-tojerusalem/9877524.

Remeikis, Amy. 2019. “"Never”: Senior Liberals in damage control after party vote to privatise ABC'. The Guardian, 17 June. www.theguardian.com/ australia-news/2018/jun/17/never-senior-liberals-in-damage-control-afterparty-votes-to-privatise-abc.

Roskam, John and Daniel Wild. 2019. 20 Policies to Fix Australia. Parliamentary Research Brief, 12 April. Melbourne: Institute of Public Affairs. ipa.org.au/wpcontent/uploads/2019/04/IPA-Research-20-Policies-to-Fix-Australia.pdf. 
Sky News Australia. 2019. 'Election Night Broadcast, 2019'. Sky News Australia, 18 May.

Special Broadcasting Service (SBS). 2019. 'Conservative hero Captain GetUp rubs up against Zali Steggall poster'. SBS News, 15 April. www.sbs.com.au/ news/conservative-hero-captain-getup-rubs-up-against-zali-steggall-poster.

Speers, David. 2019. 'Speers on Sunday'. Sky News Australia, 14 April.

Steelman, Aaron. 2003. 'Do Think Tanks Matter? Assessing the Impact of Public Policy Institutes by Donald E. Abelson'. [Book review], The Cato Journal 23(1): 163-65.

Stone, Diane. 1996. Capturing the Political Imagination: Think Tanks and the Policy Process. London: Frank Cass.

Sydney Morning Herald. 2018. 'Angus Taylor confirms government "won't be replacing” renewable energy target'. Sydney Morning Herald, 18 September. www.smh.com.au/politics/federal/angus-taylor-confirms-government-wont-be-replacing-renewable-energy-target-20180918-p504j1.html.

The Australia Institute. 2019. 'An open letter to the next Parliament of Australia'. The Age, [Melbourne], 15 May: 17.

Van Extel, Cathy. 2019. 'Proxy war: The outsiders campaigning for the major parties'. RN Breakfast, [ABC Radio], 10 May. abc.net.au/radionational/ programs/breakfast/proxy-war-the-outsiders-campaigning-for-the-majorparties/11099892.

Williams, Pamela. 2016. 'Federal election 2016: GetUp! proves force to be reckoned with'. The Australian, 9 July. www.theaustralian.com.au/nation/politics/federalelection-2016-getup-proves-force-to-be-reckoned-with/news-story/049de92ad $4 \mathrm{c} 625 \mathrm{fa} 510 \mathrm{f} 4 \mathrm{e} 2 \mathrm{c} 9563 \mathrm{~b} 813$.

Zhou, Naaman. 2019. 'Captain GetUp: Conservative group's satirical superhero debuts to ridicule'. The Guardian, 9 April. 
This text is taken from Morrison's Miracle: The 2019 Australian Federal Election, edited by Anika Gauja, Marian Sawer and Marian Simms, published 2020 by ANU Press, The Australian National University, Canberra, Australia.

doi.org/10.22459/MM.2020.21 